\title{
A New Genus and Two New Species of Pygmephoridae (Acari: Heterostigmata) Phoretic on Lasioglossum (Hymenoptera: Halictidae) in Japan
}

\author{
Kazuyoshi KUROSA* \\ Nishi-Ikebukuro 5-21-15, Tokyo 171-0021, Japan
}

(Received 16 February 2009; Accepted 3 April 2009)

\begin{abstract}
A new genus and two new species of pygmephorid mites belonging to the subfamily Neopygmephorinae are described from Japan under the names Insensilla lasioglossi and $I$. duplicis. They are known only from the adult females found attached to the halictid bees, Lasioglossum apristum (Vachal) and L. duplex (Dalla Torre), respectively. The new genus is readily distinguished from all the known genera of the family by that the prodorsum entirely lacks the so-called sensillum (=seta $s c_{1}$ ), but that the bothridium is retained though fairly reduced in size. I. lasioglossi, the type species, is easily discriminated from I. duplicis, the other member of the genus, by possession of much stronger barbs on the apices of most dorsal idiosomal setae, obviously shorter coxal setae, and so forth.
\end{abstract}

Key words: Insensilla, taxonomy, Pygmephoridae, phoretic mite, Lasioglossum, Japan.

\section{INTRODUCTION}

Pygmephoridae is one of the largest mite families of Heterostigmata (Acari). Many species of the family are known to be phoretic on insects and other animals; so far seven species, Parapygmephorus natalensis Cross, P. crossi Mahunka, P. pappi Mahunka, P. delyorum Mahunka, Sicilipes halictinis (Cross), S. costaricanus (Rack and Eickwort) and Rhinopygmephorus rhopalomelissae Kurosa ${ }^{\dagger}$ have been reported as such associates of halictid bees in the world (Cross, 1965; Kurosa, 2001a; Mahunka, 1974, 1980; Rack and Eickwort, 1979). In a previous paper dealing with pygmephorids phoretic on halictid bees in Japan (Kurosa, 2001a), I submitted a brief report on the occurrence of another new species representing a hitherto unknown genus of the subfamily Neopygmephorinae. Later, however, a careful reexamination of the mite specimens in question found on Lasioglossum (Evylaeus) apristum (Vachal) and L. (E.) duplex (Dalla Torre) has revealed that they are actually classified into two

\footnotetext{
* Corresponding author: e-mail: CQW35713@nifty.com

${ }^{\dagger}$ In some sections of the original description of this new genus and species, I carelessly misspelled the generic name as Rhynopygmephorus. Its correct name is Rhinopygmephorus as stated in the chapter of etymology.

DOI: $10.2300 /$ acari.18.17
} 
different species. The present paper is devoted to the descriptions of the above new genus and species.

The terminology of the body structures and the setal notation mainly follow those of Lindquist (1986). All measurements are given in micrometers $(\mu \mathrm{m})$.

\section{DESCRIPTIONS}

Family Pygmephoridae Cross, 1965

Subfamily Neopygmephorinae Cross, 1965

Insensilla Kurosa gen. nov.

(Figs. 1-10)

Type species: Insensilla lasioglossi sp. nov. Genus based on adult female only.

Adult female. Prodorsum (Figs. 1, 7) inversely T-shaped, medium in size, almost wholly exposed, with only 2 pairs of setae ( $v_{2}$ and $\left.s c_{2}\right)$; sensillum ( $s c_{1}=$ bothridial seta) entirely lacking, but bothridium is retained though fairly reduced in size; stigmata opening on mid-level of the shield, nearly circular, with an oblique narrow slit; seta $v_{2}$ inserted about mid-distance between stigmatal opening and base of seta $s c_{2}$, which is shaped like most of dorsal opisthosomal setae. Opisthosomal dorsum (Figs. 1, 7) with 7 pairs of setae and 2 pairs of small cupules (ia and $i h$ ); setae other than $e$ and $h_{2}$ weakly or not tapered. Anterior and posterior coxosternal plates (Figs. $2,8)$ with $4(2+2)$ and $6(3+3)$ pairs of setae, respectively. Coxal and sternal apodemes poorly developed in general; secondary transverse apodeme and apodeme 5 lacking. Posterior margin of posterior coxosterna complete. Posterior genital sclerite narrowly triangular. Three pairs of pseudanal setae present; $p s_{1}$ longer than $p s_{2}$ and $p s_{3}$. Legs I-III subequal in length; leg IV longer. Number of setae and solenidia (in parentheses) on leg segments (trochanter, femur, genu, tibia

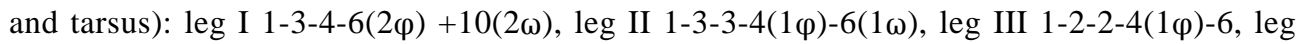
IV 1-2-1-4(1 $\varphi$ )-6. Leg I (Figs. 4, 10): femoral seta $d$ semimembranous, blade-like, reflexed forward in distal half, bluntly pointed at apex; tibiotarsus obviously wider than genu, with welldeveloped internal tibiotarsal thickening; claw pedicellate, stout, sickle-shaped, strongly dilated basally; pedicel large, irregularly cup-like, elongated along its medial margin to form a large, bluntly pointed process opposable to base of claw; 5 tarsal eupathidial setae present (probably $p^{\prime}$ absent); seta $k$ inserted at a distance from solenidion $\varphi_{1}$, eupathidial. Leg IV (Figs. 5-6): trochanter subquadrate, without distinct constriction near middle.

Etymology. Insensilla is a combination of the Latin prefix in- meaning "not, without" and the Latin noun sensillum, referring to the lack of sensillum which is characteristic of the genus. The name is feminine in gender.

Remarks. Among the many described members of Pygmephoridae, only three species, Elattoma ruehmi Mahunka, 1972, Asensilla prassei Rack, 1974 and Nipponophorus ishiharai (Kurosa, 1994) [= Termitacarus ishiharai Kurosa, 1994 (Kurosa, 2001b)] are known to entirely lack prodorsal seta $s c_{1}$ (both sensillum and bothridium) in female. On the other hand, female Geotrupophorus gozmanyi Mahunka, 1970, is described as possessing "calyciform sensillus." Certainly, Mahunka illustrates a reduced, short-stalked (?) sensillum of this species (Fig. 12-A), but its bothridium appears to be normally developed. Three of these four species belong to the 
subfamily Pygmephorinae, merely $N$. ishiharai is a member of the subfamily Neopygmephorinae. Insensilla is assigned to Neopygmephorinae because of 1) absence of setae $v_{1}$ on prodorsal plate, 2) presence of 2 pairs of cupules ( $i a$ and $i h$ ) on idiosomal dorsum, 3) presence of 2 pairs of setae on each of coxosterna I and II, 4) 4-segmented leg I, and 5) absence of seta $l^{\prime \prime}$ on femur I, and is characterized by that the prodorsal seta $s c_{1}$ (sensillum) is completely lost, but that the bothridium is retained though fairly reduced in size. Therefore, Insensilla is readily distinguished from all the known genera of the family by this feature alone.

The male and larva of the representatives of Insensilla are unknown at present, but they will be found, along with the non-phoretic female, in host bee's nest burrow in the soil.

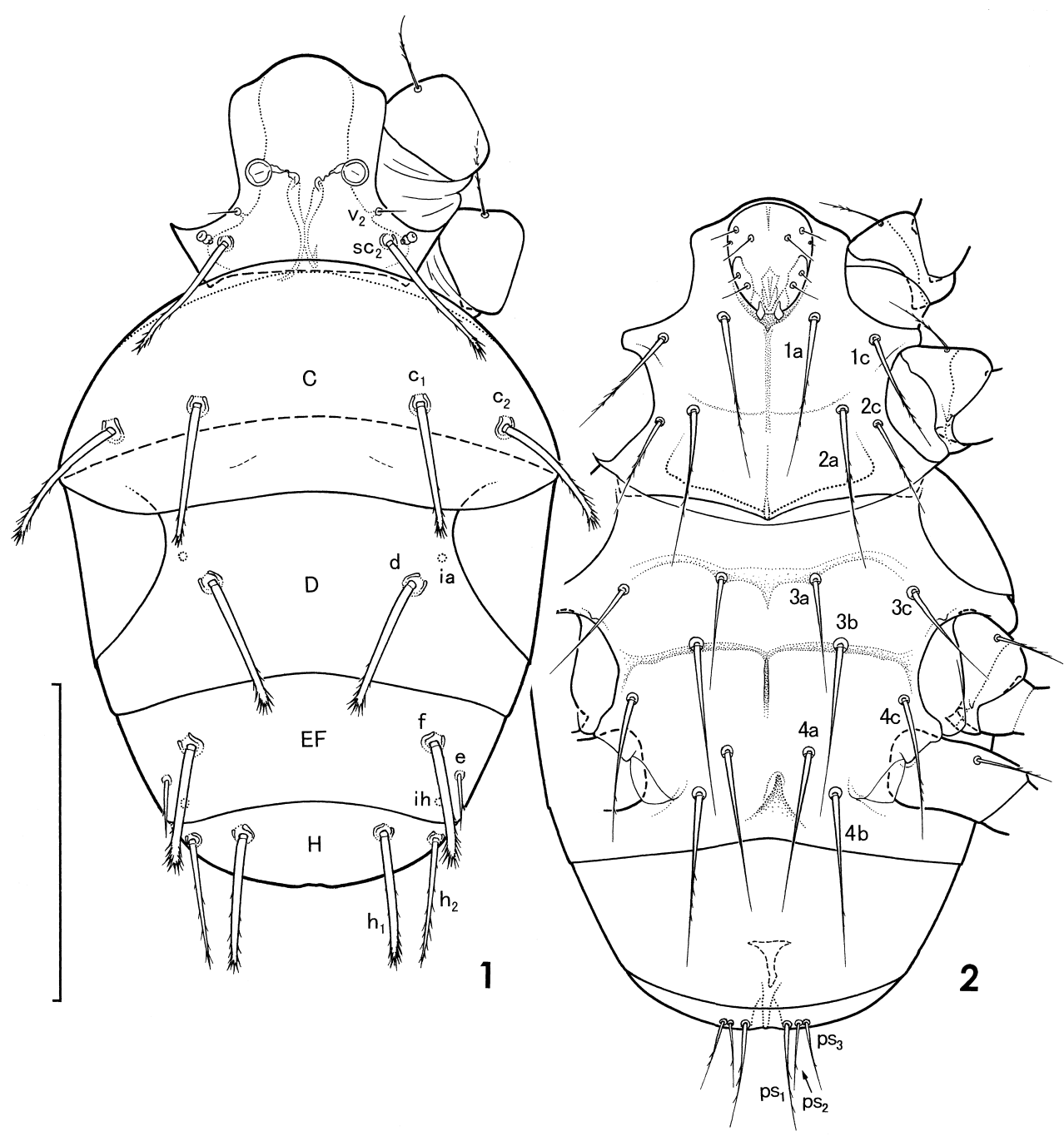

Figs. 1-2. Insensilla lasioglossi sp. nov., female, habitus. 1. dorsal aspect; 2. ventral aspect. Scale bar. $100 \mu \mathrm{m}$. 
Insensilla lasioglossi Kurosa sp. nov.

(Figs. 1-5)

ADULT FEMALE. Cuticle moderately sclerotized. Length of idiosoma 217-267, width of idiosoma 131-159, mutual distance of anterior coxo-trochanteral condyles III 96-114 (mean 103.5, $\mathrm{n}=6$ ). For the measurements of idiosomal setae, legs and, solenidia and setae on legs, see Tables 1 and 2.

Gnathosoma (Fig. 2). Capsule moderately longer than wide, with dorsal setae $c h_{1}$ and $c h_{2}$ medium in length; dorsolateral setae $p p$ minute; femurogenual seta of palpi distinctly shorter than tibiotarsal one. Pump 2 of pharyngeal muscular structure 32 in length in 1 specimen.

Idiosomal dorsum (Fig. 1). Prodorsum 53-69 in length along median line, widest at about 1/4 to $1 / 5$ from the base; anterior $1 / 2$ to $2 / 3$ somewhat divergent anteriad, with broad lateral portions well sclerotized; anterior margin rounded; posterior margin nearly straight, narrowly covered by anterior margin of opisthosomal plate C; stigmatal opening ca. 7-9 in diameter; setae $s c_{2}$ nearly as long as their mutual distance, slightly tapered like most of dorsal opisthosomal setae (though somewhat thinner), weakly barbed in distal half, but provided with some strong barbs apically. Opisthosomal dorsum: posterior margin of plate $\mathrm{C}$ broadly and shallowly emarginate medially; setae other than $e$ and $h_{2}$ subequal in length, rather short and thick, poorly or not tapered, barbed in distal half, the barbs are sparse and weak near the middle, but dense and strong apically; $c_{1}$ slightly anterior to, and nearly as long as $c_{2} ; d$ somewhat shorter than their mutual distance; $e$ inserted posterolaterad of, and 9-15 apart from $f$, small, only half as long as the latter, setiform, almost glabrous; $h_{1}$ as long as or slightly longer than their mutual distance; $h_{2}$ nearly on a level with, and 12-17 apart from $h_{1}$, subequal in length to the latter, setiform, rather weakly barbed.

Idiosomal venter (Fig. 2). Coxal apodeme 2 arcuate, sometimes almost invisible anterolaterally; prosternal apodeme frequently interrupted or barely visible in posterior half; apodeme 3 curved backward laterally, extending to near seta $3 b$; apodeme 4 nearly horizontal, sometimes weakly curved backward, reaching the thickening along ventral margin of coxal foramen III; poststernal apodeme reduced, its anterior half before junction with apodemes 4 faint or invisible. Coxal setae generally long and attenuate, feebly or not barbed; $1 a$ inserted nearly on the level of posterior junction of apodemes 1, extending much beyond level of $2 a ; 1 c$ slightly posterior to $1 a ; 2 a$ extending much beyond sejugal apodeme; $2 c$ slightly posterior to, and 8-12 apart from $2 a ; 3 a$ extending well beyond apodeme $4 ; 3 b$ inserted on apodeme 4 or nearly so, extending well beyond level of $4 a ; 3 c$ somewhat posterior to $3 a ; 4 a$ closer to level of $4 b$ than to apodeme $4 ; 4 b$ nearly on the level of posteriormost point of coxal foramen IV. Pseudanal setae $p s_{2}$ and $p s_{3}$ about $3 / 2$ as long as $p s_{1}$; arrangement of these setae somewhat variable individually; alveolus of $p s_{2}$ adjoining, or some distance apart from those of $p s_{1}$ and $p s_{3} ; p s_{3}$ on a level with $p s_{2}$ or slightly anterior to it.

Legs. All legs moderately thick. Leg I (Fig. 4): genu a little wider than long; genual seta $l^{\prime}$ thick but not very long, sparsely with strong barbs; tibiotarsus, excluding pedicel of claw, about $3 / 2$ as long as wide; distinct pinnaculum lacking, but a weak protuberance present, which bears 1 eupathidium $\left(t c^{\prime \prime}\right)$ at apex; tibiotarsal solenidia medium in size, $\varphi_{1}$ and $\varphi_{2}$ subfusiform, $\omega_{1}$ finger-shaped, $\omega_{2}$ subclavate; order in length of 4 solenidia: $\varphi_{2} \geqq \omega_{1} \geqq \varphi_{1} \geqq \omega_{2}$; seta $d$ displaced to dorsomedial surface, rather thick, sparsely provided with strong barbs; seta $p l^{\prime}$ much the longest 
of tibiotarsal setae, fine, appearing glabrous. Leg II (Fig. 3): femoral seta $d$ stout, sparsely with strong barbs; tibial solenidion $\varphi$ subbasal in position, medium-sized, subfusiform; tibial setae $v^{\prime}$ and $v^{\prime \prime}$ fairly long; tarsal solenidion $\omega$ almost basal in position, subfusiform; seta $t c^{\prime \prime}$ fairly long, almost glabrous. Leg III: femoral seta $d$, tibial setae $v^{\prime}$ and $v^{\prime \prime}$, and tarsal seta $t c^{\prime \prime}$ as described for leg II, but tibial solenidion $\varphi$ smaller and faintly visible. Leg IV (Fig. 5): femoral seta $d$ inserted nearly on a level with $v^{\prime}$, stout, poorly tapered, strongly barbed in distal half, with apex extending to, or a little beyond base of tarsus; tibial solenidion $\varphi$ subbasal in position, small, usually difficult to discern; tibial seta $d$ inserted in distal half, shaped like femoral $d$ though

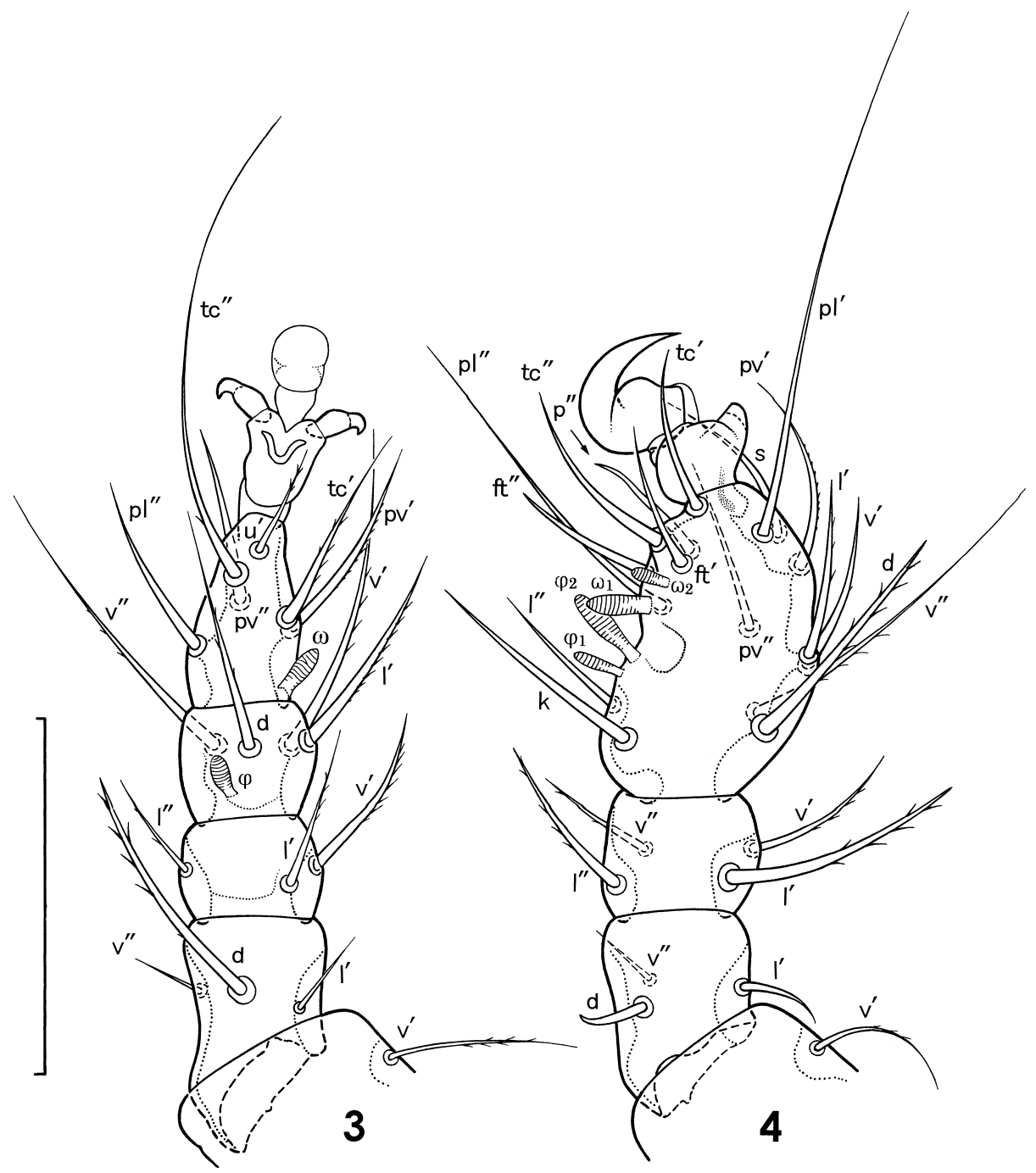

Figs. 3-4. Insensilla lasioglossi sp. nov., female, left legs, dorsal aspect. 3. Leg II; 4. leg I. Scale bar: $50 \mu \mathrm{m}$. 
somewhat shorter, with rather strong barbs mainly in distal half; $t c^{\prime \prime}$ extremely long, appearing glabrous; claws much smaller and thinner than those of legs II and III; empodium also small.

Male and larva. Unknown.

Host. Lasioglossum apristum (Vachal, 1908) (Hymenoptera: Halictidae) (det. Y. Maeta, Shimane University). Five mites were found on the metacoxa of a pinned female specimen of the bee; two mites were found on the mesopleuron of another female bee, of which one was lost after the identity with the other mite specimens had been confirmed.

Type series. Holotype (Kurosa 23176-2): female, Mt. Daisen, Tottori Pref., western Honshu,

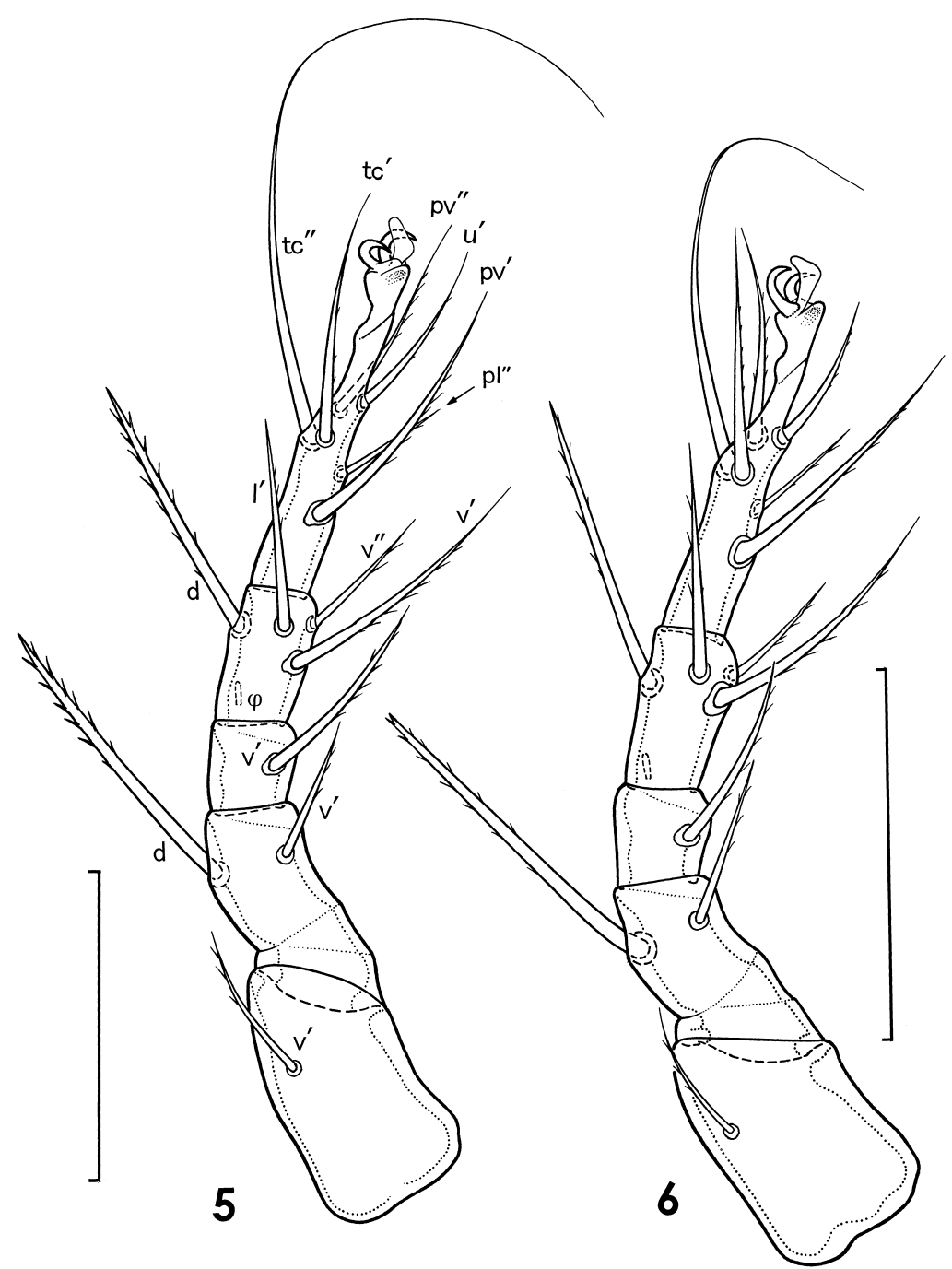

Figs. 5-6. Insensilla spp. nov., female, left legs IV, ventral view. 5. I. lasioglossi; 6. I. duplicis. Scale bars: 50 $\mu \mathrm{m}$. 
Japan, 3-X-1982, ex female Lasioglossum (Evylaeus) apristum (Vachal, 1908) (Hymenoptera: Halictidae), Y. Maeta leg. Paratypes (Kurosa 23176-1, 3 5 and 23177-1): 5 females, same data as the holotype.

The holotype is deposited in the collection of the National Museum of Nature and Science, Tokyo (NSMT), Japan. The paratypes are now retained in my private collection, but will be deposited in NSMT later. The host bee specimens of the type material, labeled "Host of mites, No. 23176 and No.23177, Kurosa 1984" are preserved in the collection of Laboratory of Life and Environmental Science, Shimane University, Matsue, Japan.

Distribution. Japan (Honshu).

Etymology. The specific name is derived from Lasioglossum, the generic name of the host bee.

Remarks. Besides the absence of prodorsal setae $s c_{1}$ (sensilla), the conformation of dorsal

Table 1. Measurements (in $\mu \mathrm{m}$ ) of idiosomal setae in Insensilla spp. nov., female; range and mean values of 3 specimens.

\begin{tabular}{|c|c|c|c|c|c|c|c|c|}
\hline \multirow{3}{*}{ Seta } & \multicolumn{4}{|c|}{ I. lasioglossi } & \multicolumn{4}{|c|}{ I. duplicis } \\
\hline & \multicolumn{2}{|c|}{ Length } & \multicolumn{2}{|c|}{ Mutual distance } & \multicolumn{2}{|c|}{ Length } & \multicolumn{2}{|c|}{ Mutual distance } \\
\hline & Range & Mean & Range & Mean & Range & Mean & Range & Mean \\
\hline$v_{2}$ & $8-11$ & 9.3 & $41-42$ & 41.0 & $8-9$ & 8.3 & $42-43$ & 42.1 \\
\hline$s c_{1}$ & 0 & 0 & $58-63$ & 60.9 & 0 & 0 & $61-66$ & 63.0 \\
\hline$s c_{2}$ & $45-49$ & 46.8 & $47-51$ & 49.6 & $43-46$ & 44.8 & $43-46$ & 44.5 \\
\hline$c_{1}$ & $42-49$ & 44.1 & $60-75$ & 66.3 & $46-47$ & 46.2 & $65-70$ & 67.7 \\
\hline$c_{2}$ & $43-48$ & 46.2 & $120-123$ & 121.8 & $53-54$ & 53.7 & $107-118$ & 112.3 \\
\hline$d$ & $40-46$ & 43.7 & $56-63$ & 60.1 & $46-48$ & 47.1 & $57-59$ & 57.7 \\
\hline$e$ & $16-20$ & 18.9 & $74-92$ & 84.9 & $21-23$ & 21.5 & $73-81$ & 77.0 \\
\hline$f$ & $40-45$ & 42.2 & $63-74$ & 70.6 & $46-48$ & 46.9 & $63-68$ & 65.3 \\
\hline$h_{1}$ & $40-45$ & 42.9 & $38-46$ & 42.6 & $49-50$ & 49.4 & $35-39$ & 36.7 \\
\hline$h_{2}$ & $39-43$ & 40.8 & $68-78$ & 74.1 & $39-46$ & 42.2 & $62-63$ & 64.2 \\
\hline $1 a$ & $45-52$ & 48.6 & $28-32$ & 30.5 & $27-29$ & 28.4 & $26-27$ & 26.6 \\
\hline $1 c$ & 33-39 & 36.9 & $64-67$ & 66.2 & $29-31$ & 29.7 & $65-69$ & 67.2 \\
\hline $2 a$ & $45-54$ & 49.2 & $47-48$ & 47.3 & $30-32$ & 31.3 & $54-57$ & 55.8 \\
\hline $2 c$ & $26-31$ & 28.9 & $64-70$ & 67.6 & 18-19 & 18.4 & $66-71$ & 68.7 \\
\hline $3 a$ & $30-37$ & 33.9 & $29-30$ & 29.8 & $25-26$ & 26.2 & $29-30$ & 29.4 \\
\hline $3 b$ & $45-55$ & 49.7 & $41-46$ & 43.9 & $25-27$ & 26.2 & $39-45$ & 42.4 \\
\hline $3 c$ & $27-37$ & 31.2 & $91-92$ & 91.6 & $18-19$ & 18.6 & $82-89$ & 85.8 \\
\hline $4 a$ & $45-52$ & 49.3 & $21-25$ & 23.7 & $30-31$ & 30.1 & $23-26$ & 24.1 \\
\hline $4 b$ & $45-57$ & 51.0 & $36-43$ & 40.7 & $30-34$ & 32.4 & $43-45$ & 43.8 \\
\hline $4 c$ & $40-46$ & 42.8 & $85-86$ & 85.4 & $24-26$ & 25.5 & $79-84$ & 81.0 \\
\hline$p s_{1}$ & $29-33$ & 31.3 & 13 & 12.8 & $25-26$ & 25.0 & 11 & 10.9 \\
\hline$p s_{2}$ & $16-20$ & 17.3 & $21-22$ & 21.0 & 14 & 13.8 & $16-17$ & 16.5 \\
\hline$p s_{3}$ & $15-20$ & 18.2 & $25-27$ & 25.9 & $17-19$ & 18.3 & $25-27$ & 26.0 \\
\hline
\end{tabular}

Mutual distance of anterior coxo-trochanteral condyles III in measured specimens of $I$. lasioglossi is 106-114 (M = 110.4) $\mu \mathrm{m}$, that of $I$. duplicis is $93-104(\mathrm{M}=96.9) \mu \mathrm{m}$. Lengths of coxal and pseudanal setae are usually difficult to take accurate measurement because of the extreme fineness of the apices; therefore the approximate values are shown. 
idiosomal setae (except $e$ and $h_{2}$ ), which are poorly or not tapered and provided with strong barbs apically, is considered the most useful character for recognizing the new species.

\section{Insensilla duplicis Kurosa sp. nov.}

(Figs. 6-10)

ADULT FEMALE. Similar to Insensilla lasioglossi, the type species of the genus, in many respects; chiefly the differential characters are described herein. Length of idiosoma 229-253, width of idiosoma 127-144; mutual distance of anterior coxo-trochanteral condyles III 93-104 (mean 96.6, $\mathrm{n}=4$ ). For the measurements of idiosomal setae, legs and, solenidia and setae on legs, see Tables 1 and 2.

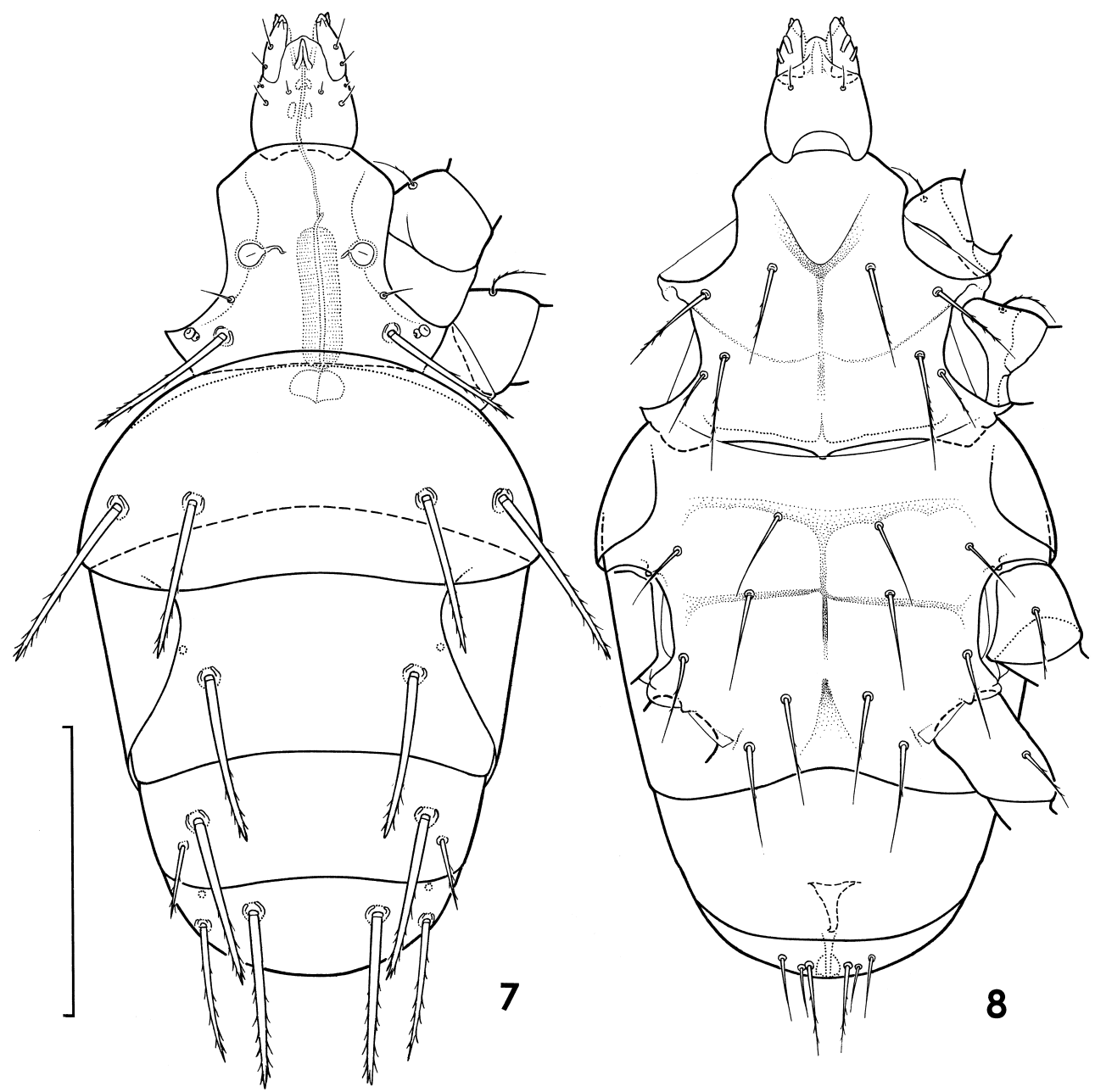

Figs. 7-8. Insensilla duplicis sp. nov., female, habitus. 7. dorsal aspect; 8. ventral aspect. Scale bar: $80 \mu \mathrm{m}$. 
Gnathosoma (Figs. 7-8). Capsule with dorsal setae $c h_{1}$ and $c h_{2}$ considerably short; femurogenual and tibiotarsal setae of palpi medium in length. Pump 2 of pharyngeal muscular structure 38 in length in 1 specimen.

Idiosomal dorsum (Fig. 7). Prodorsum 63-71 in length along median line; seta $s c_{2}$ slightly tapered like most of dorsal opisthosomal setae (though somewhat thinner), weakly barbed. Opisthosomal dorsal setae other than $e$ and $h_{2}$ generally slightly longer and thinner than in $I$. lasioglossi, slightly tapered, weakly barbed in distal $1 / 2$ to $3 / 5$, the barbs gradually becoming somewhat stronger with approach to the apex; $c_{2}$ nearly on a level with, and slightly longer than $c_{1}$; e 7-10 apart from $f$, weakly barbed; $h_{1}$ distinctly longer than their mutual distance; $h_{2}$ slightly posterior to, and 14-15 apart from $h_{1}$, somewhat shorter and obviously thinner than the latter, rather weakly barbed.

Idiosomal venter (Fig. 8). Coxal apodeme 4 nearly straight, horizontal or slightly reclinate, reaching the thickening along ventral margin of coxal foramen III; anterior half of poststernal apodeme before junction with apodemes 4 usually very weak. Coxal setae generally rather short, attenuate; most of them feebly barbed; $1 a$ barely reaching the level of seta $2 a$, which extends a little beyond sejugal apodeme; $2 c$ posterolateral to, and 8-10 apart from $2 a ; 3 a$ barely reaching apodeme $4 ; 3 b$ barely or not reaching level of $4 a$. Alveoli of pseudanal setae $p s_{1}$ and $p s_{2}$ adjoining or nearly so; alveolus of $p s_{3}$ usually somewhat anterior to, and a short or some distance apart from that of $p s_{2}$.

Legs (Figs. 6, 9-10). Legs I to IV as in I. lasioglossi, but claw and its pedicel on leg I somewhat larger, seta $t c^{\prime \prime}$ on tarsus IV not so long as in I. lasioglossi.

Table 2. Lengths (in $\mu \mathrm{m}$ ) of legs and, solenidia and selected setae on legs in Insensilla spp. nov., female; range and mean values of the same 3 specimens as those used for Table 1 .

\begin{tabular}{|c|c|c|c|c|c|c|c|c|c|}
\hline & \multicolumn{2}{|c|}{ I. lasioglossi } & \multicolumn{2}{|c|}{ I. duplicis } & & \multicolumn{2}{|c|}{ I. lasioglossi } & \multicolumn{2}{|c|}{ I. duplicis } \\
\hline & Range & Mean & Range & Mean & & Range & Mean & Range & Mean \\
\hline Leg I & $95-103$ & 99.4 & $80-90$ & 86.4 & Ge I-setal $l^{\prime}$ & $32-37$ & 35.1 & $35-36$ & 35.0 \\
\hline Leg II & $89-105$ & 98.5 & $76-90$ & 87.9 & TiTa I-seta $d$ & $32-41$ & 36.8 & $33-36$ & 34.7 \\
\hline Leg III & $95-113$ & 105.3 & $86-114$ & 97.2 & TiTa I-seta $k$ & $32-36$ & 34.1 & $27-31$ & 29.5 \\
\hline \multirow[t]{2}{*}{ Leg IV } & $139-157$ & 151.5 & $126-154$ & 136.3 & TiTa I-seta $p l^{\prime} *$ & $64-78$ & 69.8 & $58-70$ & 64.5 \\
\hline & & & & & TiTa I-seta $p l^{\prime \prime} *$ & $54-64$ & 61.0 & $44-63$ & 54.3 \\
\hline TiTa I-sol. $\varphi_{1}$ & $11-13$ & 12.1 & $9-12$ & 10.0 & TiTa I-seta $t c^{\prime \prime}$ & $26-36$ & 30.1 & $24-28$ & 26.4 \\
\hline TiTa I-sol. $\varphi_{2}$ & $6-7$ & 6.7 & $5-7$ & 6.0 & Fe II-seta $d$ & $32-37$ & 35.5 & $28-35$ & 32.9 \\
\hline TiTa I-sol. $\omega_{1}$ & $9-10$ & 9.5 & $8-11$ & 8.9 & Ta II-seta $t c^{\prime \prime} *$ & $54-67$ & 60.2 & $43-48$ & 44.6 \\
\hline TiTa I-sol. $\omega_{2}$ & $6-7$ & 6.4 & $5-6$ & 5.8 & Fe III-seta $d$ & $32-40$ & 34.5 & $32-38$ & 33.8 \\
\hline Ti II-sol. $\varphi$ & $6-7$ & 6.4 & $5-7$ & 5.9 & Ta III-seta $t c^{\prime \prime} *$ & $64-90$ & 74.7 & $56-78$ & 63.3 \\
\hline Ta II-sol. $\omega$ & $8-9$ & 8.1 & $8-9$ & 8.3 & Fe IV-seta $d$ & $45-55$ & 50.6 & $46-54$ & 49.4 \\
\hline Ti III-sol. $\varphi$ & - & - & - & - & Ti IV-seta $d$ & $40-46$ & 42.9 & $37-42$ & 39.7 \\
\hline Ti IV-sol. $\varphi$ & - & - & - & - & Ta IV-seta $t c^{\prime \prime} *$ & $89-125$ & 108.9 & $59-76$ & 66.6 \\
\hline
\end{tabular}

Legs are measured along longitudinal axis from the basalmost point of femur (legs I-III) or trochanter (leg IV) to the base of claw(s). Solenidia $\varphi$ on tibiae III and IV are barely or not measurable because of the indistinctness; therefore the values are not shown. Setae marked with asterisk (*) are usually difficult to take accurate measurement because of the extreme fineness of the apices; therefore the approximate values are shown. 
Male and larva. Unknown.

Host. Lasioglossum duplex (Dalla Torre, 1896) (Hymenoptera: Halictidae) (det. Y. Hirashima, Kyushu University). Four female mites were found on the first abdominal tergite of a dried female specimen of the bee.

Type series. Holotype (Kurosa 22837-3), female, Waritani-rindô, Ogawa-machi, Hiki-gun, Saitama Pref., eastern Honshu, Japan, 1-VIII-1978, ex female Lasioglossum (Evylaeus) duplex (Dalla Torre, 1896), (Hymenoptera: Halictidae), J. Okuma leg. Paratypes (Kurosa 22837-1 2, 4), 3 females, same data as the holotype.

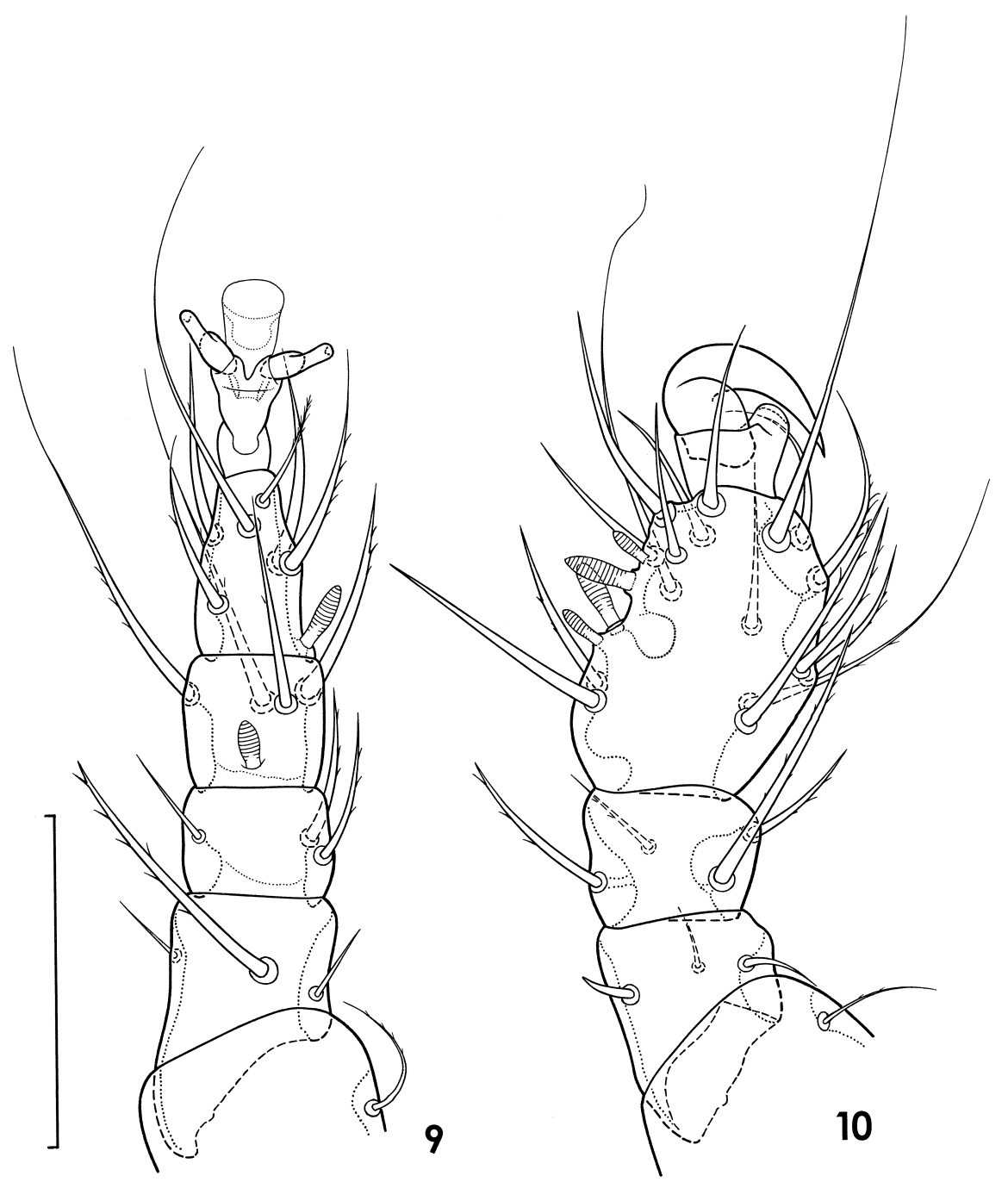

Figs. 9-10. Insensilla duplicis sp. nov., female, left legs, dorsal aspect. 9. Leg. II; 10. leg. I. Scale bar: $40 \mu \mathrm{m}$. 
The holotype is deposited in the collection of the National Museum of Nature and Science, Tokyo (NSMT), Japan. The paratypes are now retained in my private collection, but will be deposited in NSMT later. The host bee specimen of the type material, labeled "Host of mites, No. 22837, Kurosa 1984" is preserved in the collection of the Entomological Laboratory, Kyushu University (ELKU), Fukuoka, Japan.

Distribution. Japan (Honshu).

Etymology. The name duplicis is the genitive of duplex, the specific name of the host bee.

Remarks. This species is easily distinguished from the type species of the genus by the following characteristics: 1) prodorsal seta $s c_{2}$ and dorsal idiosomal setae $c_{1}, c_{2}, d, f$ and $h_{1}$ weakly barbed in distal $1 / 2$ to $3 / 5$, the barbs gradually becoming somewhat stronger towards each apex (in the type species, these setae are weakly barbed in distal half, but densely and strongly barbed apically); 2) coxal setae each much shorter than the corresponding seta of the type species; 3 ) seta $t c^{\prime \prime}$ on tarsus IV obviously shorter.

\section{ACKNOWLEDGEMENTS}

I wish to express my gratitude to Dr. Yasuo Maeta, Professor Emeritus of Shimane University, Japan and Mr. Jun Okuma, Sasebo-shi, Japan, for supplying with the material used in the study. Thanks are also due to Dr. Yoshihiro Hirashima, Professor Emeritus of Kyushu University, Japan, for his valuable advice with respect to the zoological nomenclature, and to Dr. Alexander A. Khaustov, Nikita Botanical Garden, Yalta, Ukraine, for giving me an opinion on the setal notation of pygmephorid mites.

\section{REFERENCES}

Cross, E. A. (1965) The generic relationship of the family Pyemotidae (Acarina: Trombidiformes). University of Kansas Science Bulletin, 45: 29-275.

Kurosa, K. (1994) A new genus and species of Pygmephoridae (Acari: Heterostigmata) associated with Reticulitermes spelatus kyushuensis (Isoptera: Rhinotermitidae) in Japan. Transaction of the Shikoku Entomological Society, 20: 207214.

Kurosa, K. (2001a) A new genus and species of Pygmephoridae (Acari: Heterostigmata) associated with the halictid bees in Japan. Journal of the Acarological Society of Japan, 10: 27-35.

Kurosa, K. (2001b) New replacement name for Termitacarus Kurosa (Acari: Pygmephoridae). Journal of the Acarological Society of Japan, 10: 123.

Lindquist, E. E. (1986) The world genera of Tarsonemidae (Acari: Heterostigmata): a morphological, phylogenetic and systematic revision, with a reclassification of family-group taxa in Heterostigmata. Memoirs of the Entomological Society of Canada, (136): 1-517.

Mahunka, S. (1970) Considerations on the systematics of the Tarsonemina and the descriptions of new European taxa (Acari: Trombidiformes). Acta Zoologica Academicae Scientiarum Hungaricae, 16: 137-174.

Mahunka, S. (1972) Drei neue Milben-Arten aus Südamerika (Acari: Anoetidae und Pygmephoridae). Acarologie, (17): 20-21.

Mahunka, S. (1974) Beiträge zur Kenntniss der an Hymenopteren lebenden Milben (Acari), I. Annales Historico-naturales Musei Nationales Hungarici, 66: 389-394.

Mahunka. S. (1980) Parapygmephorus delyorum sp. n., eine neue Art aus Korea (Acari: Tarsonemina). Parasitologia Hungaricae, 8: 75-83. 
Rack, G. (1974) Neue und bekannte Milbenarten der Überfamilie Pygmephoroidea aus dem Saalkreis bei Halle (Acarina,Tarsonemida). Entomologische Mitteilungen aus dem Zoologischen Museum Hamburg, 4(87): 499-504.

Rack, G. and G. C. Eickwort (1979) Biology and description of a new pygmephorid mite (Acarina: Tarsonemida) associated with the soil-nesting bee Agapostemon nasutus (Hymenoptera: Halictidae). Acarologia, 20: 267-278.

\section{摘要}

日本産 Lasioglossum（膜翅目，コハナバチ科）に便乗するヒナダニ科（ダニ目，異気門類） の 1 新属 2 新種

黒佐 和義 (東京都豊島区西池袋 5-21-15)

日本産ニジイロコハナバチ Lasioglossum (Evylaeus) apristum (Vacher) とホクダイコハ ナバチL. (Evylaeus) duplex (Dalla Torre)の成虫の体表に見いだされた 2 種のヒナダニの 雌成虫を, Neopygmephorinae 亜科に属する未記載種で新たに属を設立するべきものと認め, Insensilla lasioglossi（ニジイロコハナバチヒナダニ）およびI. duplicis（ホクダイコハナ バチヒナダニ）と命名, 記載した。 この新属の雌成虫は異気門類のダニの全般的な重要形 質である胴感毛 $\left(s c_{1}\right)$ を欠くが, 胴感盃 (bothridium) がかなり退縮しているものの，なお明瞭 に認められることで，ヒナダニ科の全既知属と明らかに異なる．なお，属の模式種である $I$. lasioglossi は $e$ と $h_{2}$ を除いた後体部背面の毛の末端部に強壮な側棘(barb) 密生することや, 基節毛が概してはるかにより長いことなどで，I. duplicis との識別は容易である. 